\title{
Mathematical Literacy Based on Metacognition on MIC Assisted PBL and Geogebra with Local Culture
}

\author{
Nurkaromah Dwidayati ${ }^{1}$, Iwan Junaedi ${ }^{2}$, Nofiana Ika Rahmawati ${ }^{3}$ \\ \{noengkd_unnes@yahoo.co.id ${ }^{1}$, iwanjunmat@gmail.com ${ }^{2}$,nofiana91.nr@gmail.com ${ }^{3}$ \} \\ Mathematic Department FMIPA Universitas Negeri Semarang ${ }^{1,2}$, SMP PGRI 15 Sukolilo, Pati, Jawa \\ Tengah, Indonesia ${ }^{3}$
}

\begin{abstract}
This study aims to: (1) test the effectiveness of mathematics learning use MIC assisted PBL and GeoGebra with local culture towards students' mathematical literacy; (2) find mathematical literacy patterns of grade VIII students' based on metacognition on MIC assisted PBL and GeoGebra with local culture. This study use mixed method with concurrent embedded design. The research subjects were students of class VIIIA at SMP PGRI 15 Sukolilo. The data were analyzed qualitatively and quantitatively. The results showed: (1) mathematics learning use MIC assisted PBL and GeoGebra with local culture is effective towards students' mathematical literacy; (2) found patterns of mathematical literacy varies in each group, such as: (a) the high metacognition students have excellent capabilities on four aspects of mathematical literacy, two aspects are less controlled and does not have capabilities on one other aspect; (b) the medium metacognition students have excellent capabilities on one aspect of mathematical literacy, one aspect is well-controlled, and five aspects others are not controlled; (c) the low metacognition students have medium capabilities on aspect of mathematical literacy, and does not have capability on six aspects other.
\end{abstract}

Keyword(s) : Mathematical Literacy, Metacognition, PBL, MiC, GeoGebra

\section{Introduction}

Mathematical literacy is defined as students' capacity to formulate, employ and interpret mathematics in a variety of contexts [1]. To improve students' mathematical literacy skills, teachers need to design and implement innovative mathematics learning, using appropriate, and varied learning models[2][3][4].

The low mathematical literacy abilities are influenced by low metacognition[5]. Metacognition is a person's ability to reflect on his own thought process, is something unique, and plays an important role in one's consciousness [6]. By looking at the students metacognition, the teacher can know the flow of students' thinking in problem solving so that it can be used as an evaluation and feedback material [7].

The learning model which is considered to be able to accommodate the development of student metacognition is the Problem Based Learning (PBL). PBL is a learning model that describes the learning conditions in which problems become control in learning so that students have the opportunity to think high-level, submit creative ideas, and communicate with friends mathematically[8][9].

One of the learning approaches that can be used is the Mathematic in Context (MiC). Mathematics learning with the MiC approach can associate mathematics with any context in 
order that it can provide a broad range of active thinking and be able to attract students' interest in answering problems through various strategies that spur the mathematical development [10].

This study integrates the MiC approach with the local culture of Pati district. The building cultural and non-cultural heritage and traditional food has relations with mathematical concepts such as flat building, building space, set, symmetry, statistics, and social arithmetic [11]. The selection of models and learning approaches can be integrated with media. The use of media in learning can foster creativity and efforts to solve problems related to learning [12]. One of the media that can support mathematics learning is GeoGebra. The use of GeoGebra in the learning has some benefits such as: (1) the GeoGebra application allows students to learn mathematics independently; (2) through the visual and geometric appearance of the mathematical concept in GeoGebra encourages students to actively think in finding relationships and drawing conclusions from objects and mathematical concepts; (3) using features available in GeoGebra, students can practice presenting ideas and explain ideas obtained from mathematical visual objects [13]. This is in line with the results of study conducted by Bulut which stated that the use of GeoGebra can improve the mathematical understanding concept of students [14].

Based on the above background, this study was intended to (1) test the effectiveness of mathematics learning use MIC assisted PBL and GeoGebra with local culture towards students' mathematical literacy, (2) find mathematical literacy patterns of grade VIII students' based on metacognition on MIC assisted PBL and GeoGebra with local culture.

\section{Methods}

This study was a quantitative and qualitative research (mixed method) with concurrent embedded design type. The quantitative design was quasi experiment. This study was conducted at SMP PGRI 15 Sukolilo by using a population of students of grade VIII in the academic year of 2017/2018. The sample was chosen by simple random Sampling technique. The results of the initial grade VIII test ability are homogeneous so that VIII A class was as the experimental class with PBL learning with MiC approach assisted with GeoGebra based local culture, and VIII B class as the control class that applied the PBL model with the scientific approach.

The data were obtained from the results of the metacognition questionnaire, the results of the mathematics literacy ability test (MLAT), and the learning implementation observation sheet. The MLAT results were used as a source of quantitative research data, and the MLAT answer sheet and the metacognition questionnaire were used as the qualitative data sources.

Quantitative data were tested using normality test, homogeneity test, proportion completeness test, average completeness test, average comparison test, and proportion comparison test. Qualitative data analysis was done by using data validation by experts validator, making verbal data transcripts, data reduction, data presentation, and data verification.

\section{Result and Discussion}

The average score of the learning instrument validation is 4.31 and the average score for the validation of the research instrument is 4.05 . The score of each instrument can be seen in table 1 and table 2 . 
Table 1. Result of validations of Learning Instruments

\begin{tabular}{lcc}
\hline \multicolumn{1}{c}{ Instrument } & Score & Criteria \\
\hline Syllabus & 4.48 & Excellent \\
RPP (Lesson Plan) & 4.26 & Excellent \\
LKPD & 4.18 & Good \\
\hline
\end{tabular}

Table 2. Result of validations of Research Instruments

\begin{tabular}{lcc}
\hline \multicolumn{1}{c}{ Instrument } & Score & Criteria \\
\hline Questionnaire of metacognition & 4.16 & Good \\
MLAT Pre & 4.11 & Good \\
MLAT Post & 4.11 & Good \\
Interview guideline & 3.79 & Good \\
Observation sheet Implementation of learning & 4.10 & Good \\
\hline
\end{tabular}

Based on the table 1 and table 2, it can be concluded that the learning instruments and the research instruments are included in the good and feasible categories to be used in the study. The results of observations of the learning implementation can be seen in tabel 3 .

Table 3. Result of Observation of the Implementation of Learning

\begin{tabular}{cccl}
\hline Meeting & Average Score & Percentage & Criteria \\
\hline 1 & 4.60 & $92.0 \%$ & Excellent \\
2 & 4.76 & $95.2 \%$ & Excellent \\
3 & 4.72 & $94.4 \%$ & Excellent \\
4 & 4.72 & $94.4 \%$ & Excellent \\
\hline
\end{tabular}

Based on the table 3 it can be seen that the average score of the observation results of the learning implementation is 4.70 and it is included in the excellent category. Therefore, it can be interpreted that the learning carried out during the research was in accordance with the RPP (Lesson Plan). From the assessment of the learning outcomes, the results of the MLAT are normally distributed and homogeneous. Based on the results of the proportion test obtained the value of completeness proportion of $79.3 \%$ with the value of $z_{\text {count }}$ is 0.536 and $z_{\frac{1}{2}(1-\alpha)}$ at 1.96 ; so that $-z_{\frac{1}{2}(1-\alpha)}<z_{\text {count }}<z_{\frac{1}{2}(1-\alpha)}$, which means that the proportion of students' mathematical literacy completeness in learning use MiC assisted PBL and GeoGebra with local culture reached $75 \%$.

Based on the results of the calculation of different proportions test, obtained a value of $\mathrm{z}_{\text {count }}$ at 4.90 and $z_{(0.5-\alpha)}$ at 1.64. Since $z_{\text {count }}>z_{(0.5-\alpha)}$ therefore, the proportion of completeness of mathematical literacy ability of students in learning use MiC assisted PBL and GeoGebra with local culture was more than the proportion of students' mathematical literacy ability completeness which gained PBL learning with the scientific approach.

The average value obtained from the average completeness test is 64.16 with the value of $t_{\text {count }}$ at 1.922 and $t_{(1-\alpha), d k}$ at 1.703. So that $t_{\text {count }}>t_{(1-\alpha), d k}$ which means the average value of mathematical literacy abilities of students in learning use MiC assisted PBL and GeoGebra with local culture is more than 60 . Based on the results of the calculation of the average 
difference test, obtained a value of $t_{\text {count }}$ at 5.050 and $t_{(1-\alpha), d k}$ at 1.673. Since $t_{\text {count }}>t_{(1-\alpha), d k}$ therefore, the average mathematical literacy abilities of students in learning use MiC assisted PBL and GeoGebra with local culture is more than the average of mathematical literacy ability of students who obtained PBL learning with the scientific approach.

\section{a. Pattern of the Mathematical Literacy of Students with High Metacognition}

Based on the results of completion of the metacognition questionnaire, obtained $13.79 \%$ students who had high metacognition. The average MLAT value of students in this group is 72.75. From the results of the MLAT, it was found that students with high metacognition have mathematical literacy abilities that were not faraway different. On the communication aspect, $60 \%$ of students could write down information obtained from the learning, the problems being asked, concepts and steps of completion, and could write conclusions correctly, accurately and completely. Meanwhile, the other $40 \%$ still have errors when drafting the draft solution and in writing down some mathematical symbols.

In the mathematising aspect, $40 \%$ of students could identify the mathematical structure underlying the problem, made a hypothesis, used understanding in a context, however, have not consistently written it into mathematical symbols, and have not understood the level and boundaries of the solutions caused by the model of math used. There were $40 \%$ of students could only mention the identified and asked variables. Meanwhile, the other $20 \%$ have been able to simplify the problem in the form of mathematics and made hypotheses, however, there were still errors in the calculation process.

In the representation aspect, $80 \%$ of students could understand the problems, conceptualized the solution by connecting various representations related to the problem situation. Meanwhile, the other $20 \%$ could not connect various representations related to the existing problem situations.

In the aspect of reasoning and argumentation, $80 \%$ of students could explain, maintain, and justify the completion concepts, processes, and procedures used, even though the concepts and solutions produced were not appropriate. Meanwhile, the other $20 \%$ were still uncertain about the concept and procedure for completion.

In the aspect of devising strategies for solving problems, $80 \%$ of students did not succeed in drafting solutions to contextual problems, did not have the ability to control the process when determining solutions, and did not implement strategies to evaluate the results obtained. Students with high metacognition who have the ability to devising strategies for solving problems were only $20 \%$.

In the aspects of using symbolic, formal and technical language and operation, there were $60 \%$ of students have written mathematical symbols correctly and understand the meaning of the symbols written. Learners could connect the context of the problem with the description of the solution, so that the calculation process and procedures could be done correctly. Meanwhile, the other $40 \%$ were able to identify the mathematical symbols, however, did not write the symbols correctly.

In the aspects of using mathematical tools, $40 \%$ of students were only able to identify the basic functions of mathematical tools. Students in this group have not been able to use the mathematical tools properly. For example, in drawing objects using a ruler, students did not use a scale. Meanwhile, the other $60 \%$ did not resolve the problems given. The following are the results of the work of students with high metacognition on the aspects of representations and devising strategies for solving problems. 
To test the mathematical literacy ability in the aspects of representation, the researcher used the problem of "Makam Mbah Tabek". Students were asked to calculate the total area of the tomb roof made of zinc measuring $500 \mathrm{~cm} \mathrm{x} 100 \mathrm{~cm}$ where each of the roof consists of 6 sheets of zinc. At the next point, students were asked to calculate the number of multiroof tiles measuring $770 \mathrm{~mm} \times 1000 \mathrm{~mm}$ needed to replace the zinc roof.

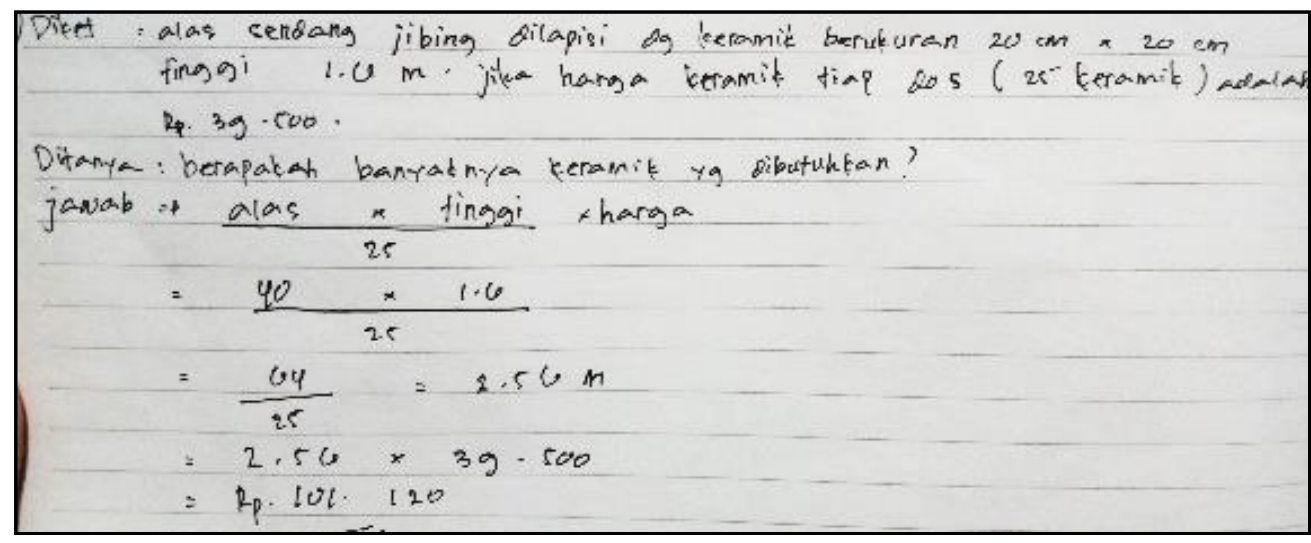

Figure 1. Result of MLAT of Students with High Metacognition in the Aspect of Representations

From figure 1, it can be seen that students can solve the problem correctly, even though the writing was still less structured. Therefore, it can be interpreted that students could understand the problems presented and were able to make a mathematical representation of the problem. At the next point, students also managed to calculate the number of multiroof tiles needed. Therefore, at this stage students have succeeded in combining the results of previously obtained representations to solve the next problem. To test the mathematical literacy ability in the aspect of devising strategies for solving problems, researchers used problems about "Sendang Jibing". Students were asked to calculate the number of ceramics needed to coat the walls and base of the spring.

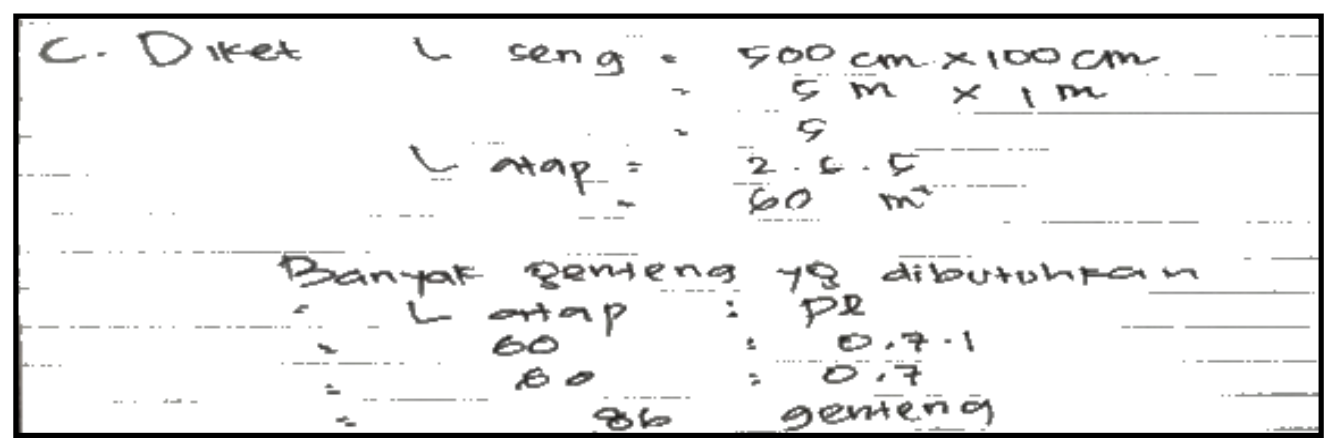

Figure 2. Result of MLAT of Students with High Metacognition in the Aspect of Devising Strategies for Solving Problem 
From figure 2, it can be seen that students could not solve the problem correctly. The concept design that was made looks original, which was by multiplying all the identified variables. Therefore, students were not able to understand the concept of completion that is made and could validate the results that have been obtained.

Students with high metacognition will have good mathematical literacy ability if they have the desire to learn from within themselves, have the ability to understand problems, skills in designing and applying a concept of completion and the ability to re-examine answers. Generally, during the problem solving process, students are aware of what is done, show ability to maintain arguments that support the accuracy of their thinking, check through re-calculation and make revisions if needed, and believe what they have done. This result is in accordance with the statement stated by Ozsoy that students who have high metacognition knowledge and ability can directly direct their learning method well [15]. Likewise, Woolfolk stated that the ability of metacognition is useful for regulating thinking in the learning [16].

\section{b. Pattern of Mathematical Literacy of Students with Medium Metacognition}

Students with medium metacognition were $72.42 \%$. The average MLAT in this group is 66.28. From the results of the MLAT, it was found that there are variation of mathematical literacy abilities of students in this group. In the communication aspect, students were able to write the information that is idetified, asked, and were able to write conclusions from the results obtained. Some students could design the concept of completion appropriately. The draft concept of $65 \%$ of students were nearly correct, and the other $35 \%$ were still conduct many mistakes.

On the mathematising aspects, there were $20 \%$ of students could identify the variables and mathematical structures underlying the problem, made a hypothesis even though the solutions obtained were still not correct. There were $75 \%$ students were lacking of ability in identifying the variables underlying the problem and could not make hypotheses. There were $5 \%$ could identify variables and made hypotheses correctly.

In the representation aspect, there were $70 \%$ of students could not make mathematical representations of the information provided, and were unable to use and interpret results in various formats related to the problem situation. There were $15 \%$ of students were lack of ability in the process of combining and evaluating two or more representations related to the problem, and the remaining $15 \%$ have good representation ability.

In the aspect of reasoning and argument, $30 \%$ of students were still unable to explain, maintain, and provide justification for the concepts and completion procedures used. $65 \%$ of them could explain and provide justification for the concepts and procedures for completion even though the concept of settlement made was still inaccurate, and the other $5 \%$ have good reasoning and argumentation ability.

In the devising strategies aspect for solving problems, there were $75 \%$ of students could not design solutions for contextual problems, did not have the ability to control processes or procedures in determining solutions, and did not know how to interpret, evaluate and validate solutions. There were $15 \%$ of students could design a solution to a contextual problem, have the ability to control the process or procedure in determining a solution, however, did not know how to evaluate, and validate the solution. Meanwhile, the other $10 \%$ did not resolve the problems given.

In the aspect of using symbolic, formal and technical language and operation, $10 \%$ of students could use mathematical symbols, understand the meaning of the symbols used, could use algorithms, and could connect the context of the problem with the solutions obtained. Meanwhile, $90 \%$ of students understand the mathematical symbols, however, have not written 
these symbols correctly, and lack of the ability to connect the context of the problem with the solutions obtained.

In the aspects of using mathematical tools, students were already having sufficient knowledge about the benefits of mathematical tools, however, have not been able to use the tools properly. The following were the MLAT results of students with medium metacognition on the aspects of communication and reasoning and argument.

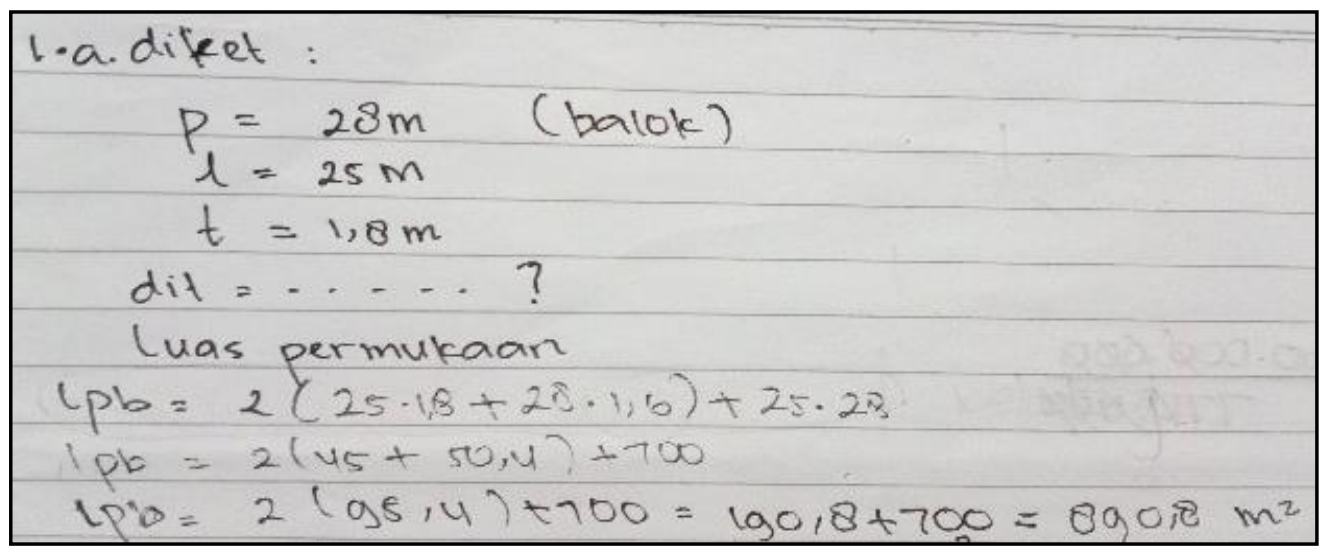

Fig.ure 3. Result of TKLM of Students with Medium Metacognition in the Aspect of Communication

To find out the mathematical literacy ability in the communication aspect, the researcher emphasized on the written communication ability. This ability can be seen from the completeness of the students in writing down the elements that were identified, asked, and the draft concepts and the completion procedures that were made.

From figure 3, it can be seen that students were able to write these elements completely. The draft concepts and procedures for the settlement that were made were also correct, including the writing of the mathematical symbols. Therefore, these students have good communication ability.

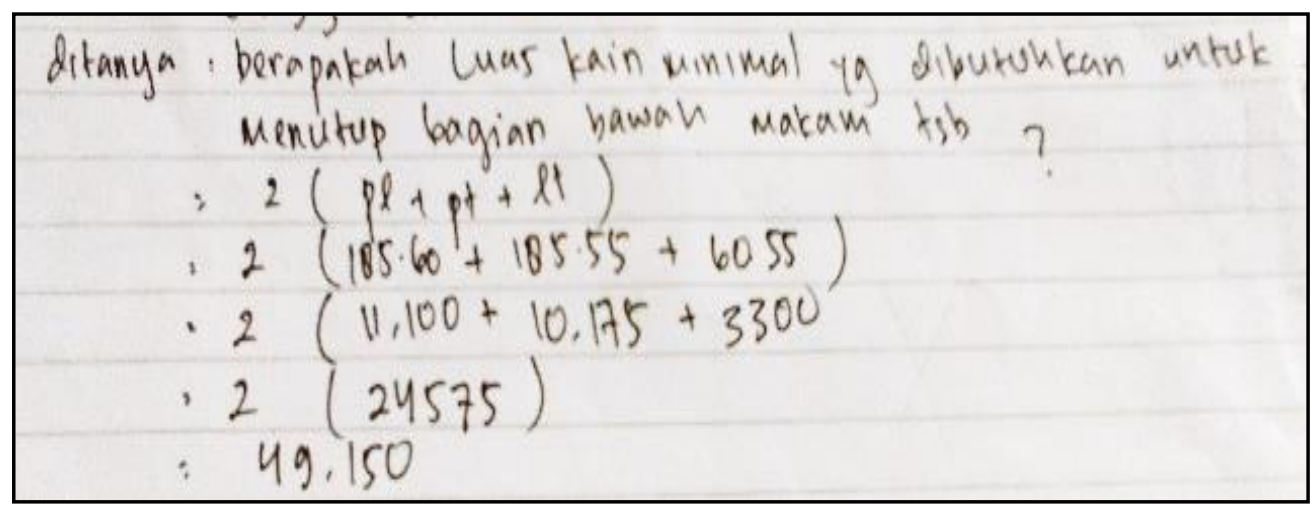

Figure 4. Result of MLAT of Students with Medium Metacognition in the Aspect of Reasoning and Argument 
To test the mathematical literacy ability in the aspects of reasoning and argumentation, the researcher used the problem of the "Makam Sunan Prawoto". Students were asked to calculate the minimum fabric area needed to cover the sides of the tomb. From figure 4, it can be seen that students with metacognition were using the formula for the surface area of the beam. Therefore, it can be inferred that students understand that the tomb is in the form of a beam. However, students did not realize that the fabric only surrounds the upright sides of the tomb, so that they still calculated the upper and lower sides.

The mathematical literacy ability shown by students with medium metacognition is based on a different awareness in recognizing problems, however, they can provide reasons for choosing the thinking or ideas. In the process of problem solving, students with medium metacognition are trying to check their thoughts, realize their mistakes, however, have not been able to think about the process of correcting the errors and still show doubts on their thinking.

\section{c. Pattern of Mathematical Literacy of Students with Low Metacognition}

From the results of completion of the metacognition questionnaire, it is found that $13.79 \%$ students have low metacognition. The average value of the MLAT results for this group is 46.00. Students in this group have mathematical literacy abilities that were not far away different. In the communication aspect, students have been able to write about the information identified and asked on the problem. However, still could not explain the procedure for solving the problem presented.

In the mathematising aspect, $50 \%$ of students could determine the variables that underlie a problem. However, were still incomplete. Students could not use understanding to speed up the completion process, and did not understand the limits of the solution produced.

In the representation aspect, students could not make mathematical representations of the real situation, so that the ability to connect various mathematical representations of a problem were still not exist. Likewise, in the aspects of reasoning and argument, students could not explain, maintain, and provide justification for the draft concepts made as well as the process or procedure in finding solutions to the problems given.

In the aspect of devising strategies for solving problems, students did not have the ability to design a settlement plan for a contextual problem, did not have the ability to control the process or procedure in determining a solution, and did not know the procedures to interpret, evaluate, and validate the solution. From the results of the MLAT analysis, students did not apply certain strategies in solving problems, however, they immediately carried out the calculation process carelessly.

In the aspect of using symbolic, formal and technical language and operation, there were $25 \%$ of students understood some mathematical symbols. However, they did not pay enough attention to the differences between the symbols. For example, in writing symbols of area and width, both are written with the same symbol, namely "L". Likewise, when writing symbols of lenght, $75 \%$ wrote them with "P".

In aspects of using mathematical tools, students were not used to apply the mathematical tools to solve problems. For example, in sketching a flat figure, students did not use a ruler or other tools. In addition, students in this group only knew the names of some mathematical tools but did not know how to use the tool correctly. The following is an example of the results of the work of students with low metacognition on communication and mathematising aspects. 


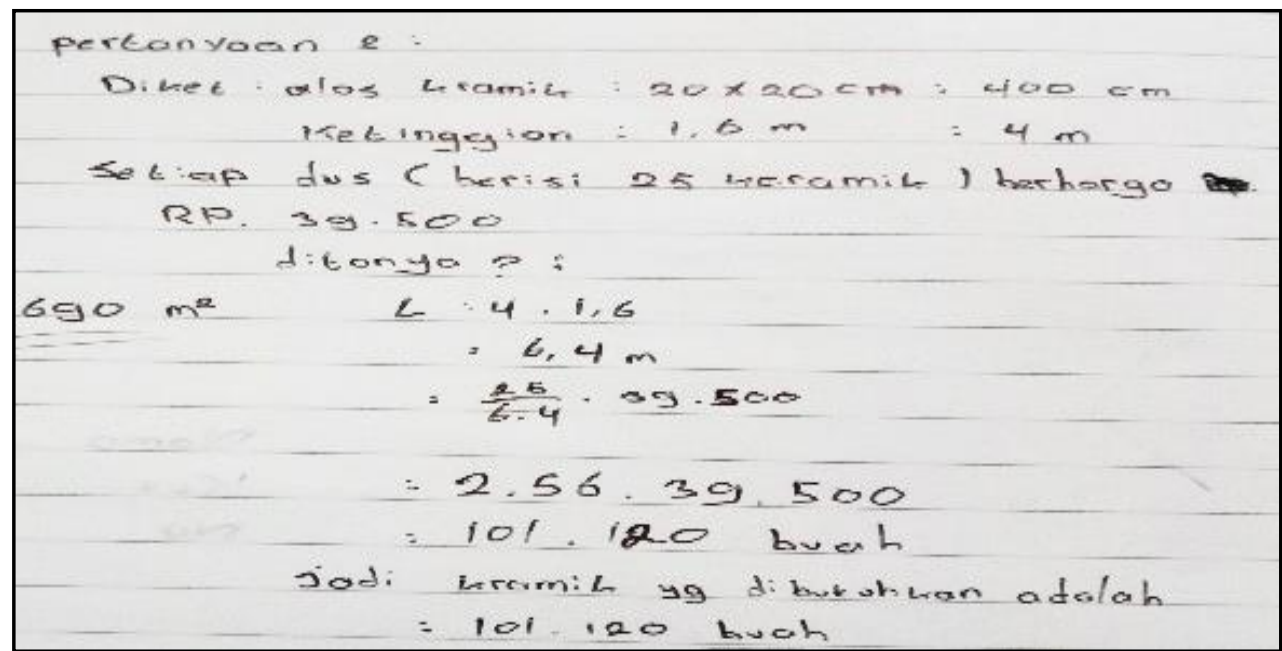

Figure 5. Result of MLAT of Students with Low Metacognition in the Aspect of communication

From figure 5, it can be seen that students could identify the existing information, and asked in the questions. However, they have not been able to design the concept of completion and explain the completion procedure. This means that communication ability in students with low metacognition begin to appear, but not well applied.

To find out the mathematical literacy ability in the mathematising aspects, the researcher used problems about "Sendang Jibing". Students were asked to calculate the number of ceramics needed to coat the base and walls of the spring. In this problem the researcher added several variables that were not needed in the completion process to test the students' ability to identify some important variables

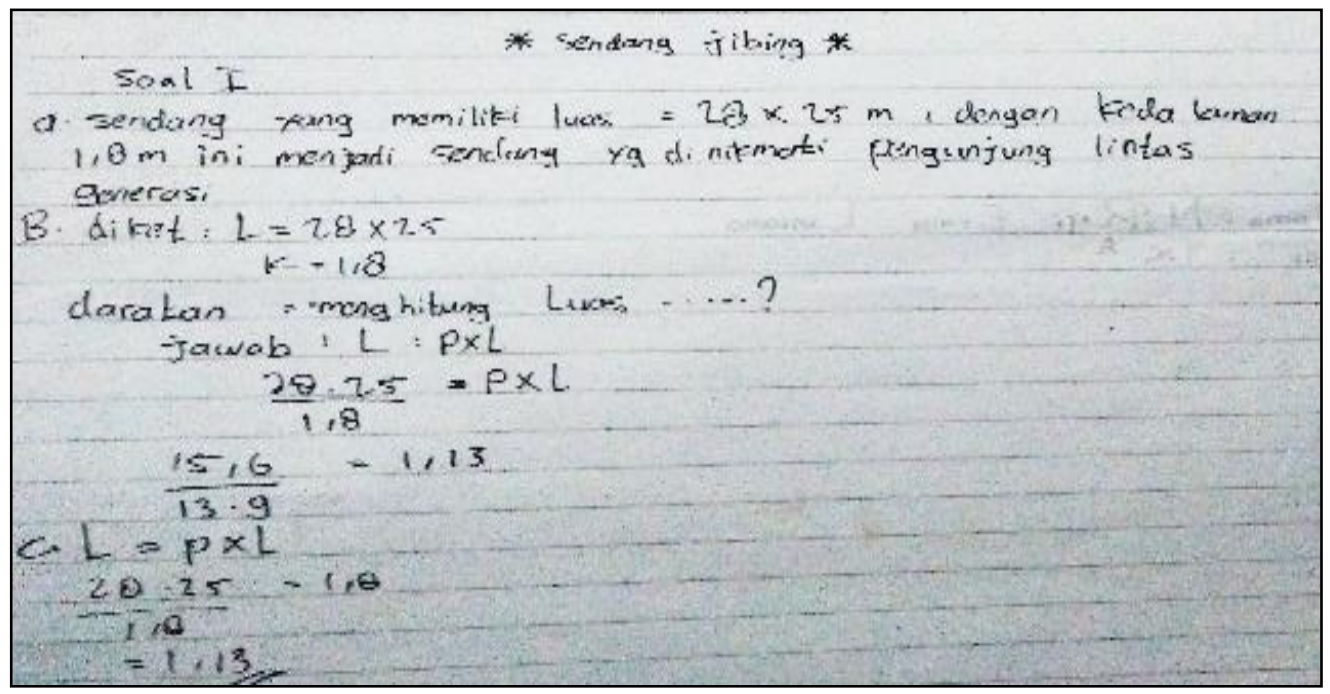

Figure 6. Result of MLAT of Students with Low Metacognition in the Aspect of mathematising 
From figure 6, it can be seen that students with low metacognition could not identify the variables needed to solve a problem. The draft design that was made did not produce the expected solution. This indicated that students with low metacognition did not understand the problem well.

MLAT results of students with low metacognition indicated that there is not enough awareness on their thought. They tend to not understand the problem and are not aware of their thought or ideas. The understanding that they have in solving problems, including in instrumental understanding [17], is a type of understanding related to the use of methods or rules without identifying the reason for using the method. In the problem solving process, students with low metacognition often do calculations carelessly. This results in the mathematical literacy abilities of students with low metacognition that are not as good as students with high and medium metacognition

\section{Conclusion}

Mathematics learning use MIC assisted PBL and GeoGebra application with local culture is effective towards students' mathematical literacy. Indicators of success can be seen from the fulfilled of classical, individual completeness, average and proportion of mathematical literacy ability of students in learning use MiC assisted PBL and GeoGebra with local culture is more than students who have obtained PBL learning with the scientific approach. From the results of the analysis of mathematical literacy ability reviewed from the metacognition, it was found some patterns of mathematical literacy abilities that varied in each group. In the students with high metacognition, there were some students who have the ability of communication, representation, reasoning and argumentation, using formal symbolic and technical language and operation that were excellent, however, they were still lacking of ability in the mathematising aspects and using mathematical tools and did not mastering the aspect of devising strategies for solving problems. In the students with medium metacognition, there were some students who have excellent communication ability. The aspect of mathematising, representation, using mathematical tools could be mastered quite well. Meanwhile, there were only several students that could mater the aspects of reasoning and argumentation, using formal symbolic and technical language and operation. However, the devising strategies for solving problems have not been mastered. In the students with low metacognition, there were some students who have good communication ability, and have no ability in six other aspects of literacy, such as mathematising, reasoning and arguments, representation, devising strategies for solving problems, using symbolic, formal and technical language and operation. 


\section{References}

[1] OECD : PISA 2015 Assessment and Analytical Framework: Science, Reading, Mathematic and Financial Literacy. Paris: OECD Publishing (2016)

[2] Junaedi, I. \& Asikin, M.:Pengembangan Pembelajaran Matematika Humanistik untuk Meningkatkan Kemahiran Matematis. Unnes Journal of Mathematics Education Research. pp. 114 - 120 (2012)

[3] Wardono: Peningkatan Literasi Matematika Melalui Pembalajaran Inovatif Berpenilaian Programme For International Student Assessment. Seminar Nasional Evaluasi Pendidikan Tahun 2013 Universitas Negeri Semarang di Semarang (2013)

[4] Rochmad \& Masrukan: Studi Kinerja Mahasiswa dalam Menganalisis Materi Pada Pembelajaran Kooperatif Resiprokal" Jurnal Kreano. pp. 47 - 57 (2016)

[5] Wahyuningsih, P., \& Waluyo, S.B.: Kemampuan Literasi Matematika Berdasarkan Metakognisi Siswa Pada Pembelajaran CPM Berbantuan Onenote Class Notebook. Unnes Journal of Mathematics Education Research. Pp. 1 - 9 (2017)

[6] Sukestyarno: Olah Data Penelitian Berbantuan SPSS. Semarang: Unnes Press (2015)

[7] Diyarko: Analisis Kemampuan Literasi Matematika Ditinjau Dari Metakognisi Pada Pembelajaran Inkuiri Berbantuan Lembar Kerja Mailing Merge. Unnes Journal of Mathematics Education Research. pp. 70 - 80 (2017)

[8] Roh, Kyeong Ha : Problem-Based Learning in Mathematics. Dalam ERIC Digest. ERIC Identifier: EDO-SE-03-07. [Online].Tersedia:http://www.ericdigest.org/ (2003)

[9] Pansa, H. E.: Problem Based Learning dalam Pembelajaran Matematika. In Prosiding Konferensi Nasional Penelitian Matematika dan Pembelajarannya (KNPMP I) 703. Surakarta: Universitas Muhammadiyah Surakarta (2016)

[10] Fasha, E. K.: Pembelajaran Matematika dengan Pendekatan Mathematics In Context pada Kemampuan dan Keterampilan Berpikir Kreatif. JES-MAT. pp. 87 - 94 (2017)

[11] Dwidayati, N.: Pengintegrasian Etnomatika dalam Pembelajaran Berbasis Masalah. PRISMA. pp. 516 - 521 (2018)

[12] Isnaini, R., Dewi, N.R., Agestanto, A., \& Asih, T.S.N.: Pendampingan Perancangan Media Pembelajaran Berbasis Konservasi pada MI Roudhotul Huda Sekaran Kecamatan Gunungpati Semarang. PRISMA. pp: $547-550$ (2018)

[13] Rahmadi, A.Z., Sari, N.P., Juliana,S., \& Rahman, B.: Studi Literatur: Pembelajaran Matematika dengan Menggunakan GeoGebra dalam Meningkatkan Kemampuan Penalaran Matematis Siswa. Prosiding Seminar Nasional Matematika dan Pendidikan Matematika UNY. Yogyakarta: Universitas Negeri Yogyakarta (2015)

[14] Bulut, M.,Akcakin, H.U., Kaya, G., \& Akcakin, V.: "The Effects of GeoGebra On Third Grade Primary Students' Academic Achievement in Fractions". IEJME-Mathematics Education. pp. 347 - 355 (2015)

[15] Ozsoy, G., Memis, A., \& Temur, T.: "Metacognition, Study Habits and Attitudes." International Electronic Journal of Elementary Education. pp. 154 - 166 (2009)

[16] Woolfolk, Anita: Educational Psychology: Active Learning Edisi Kesepuluh Bagian Kedua. Yogyakarta: Pustaka Pelajar (2009)

[17] Laurens, T : Penjenjangan Metakognisi Siswa yang Valid dan Reliabilitas. Jurnal Pendidikan dan Pembelajaran. pp. $201-210$ (2010) 